УДК $550.4: 553+553.41$

\title{
СТРАТЕГИЧЕСКИЕ МЕТАЛЛЫ ТИТАНОНОСНЫХ РОССЫПЕЙ, СВЯЗАННЫХ С АРИАДНЕНСКИМ МАССИВОМ ГИПЕРБАЗИТОВ (ПрИМОрЬ)
}

\author{
Молчанов В. П. ${ }^{1}$ Андросов Д. В. ${ }^{2}$ \\ ${ }^{1}$ ФББУН Дальневосточный геологический институт ДВО РАН, г. Владивосток \\ ${ }^{2}$ Общество с ограниченной ответственностью «ИТЕР», г. Дальнереченск \\ E-mail: vpmol@mail.ru
}

\begin{abstract}
Многолетняя интенсивная добыча благородных металлов из россыпей Приморского края привела к истощению их геологических запасов. Укрепление сырьевой базы региона связано с комплексными экзогенными месторождениями, в которых стратегические металлы являются попутными компонентами. Изучен состав ильменита, самородного золота и железистой платины титаноносных россыпей, пространственно и генетически связанных с Ариадненским массивом базит-гипербазитов (левобережье р. Большая Уссурка). Полученные данные позволили сделать вывод об участии в россыпеобразовании полигенных и полихронных коренных источников. В роли поставщика ильменита, платины, медистого и ртутистого золота выступали мафит-ультрамафиты. Другим источником питания россыпей, по-видимому, послужили кварцево-жильные образования с золото-сурьмяной минерализацией. Опыт выделения из множества полезных ископаемых стратегического минерального сырья требует внимательного изучения применительно к условиям Дальневосточного региона.
\end{abstract}

Ключевые слова: гравитация, электромагнитная сепарация, ильменит, платина, серебристое, медистое и ртутистое золото, титаноносные россыпи, мафит-ультрамафиты, Ариадненский массив, Приморье.

DOI: 10.34078/1814-0998-2020-3-3-10

\section{ВВЕДЕНИЕ}

Приморье относится к числу наиболее старых районов золотодобычи. Известно, что здесь «еще в древности добывали россыпное золото... Особенно грандиозны древние выработки по Бабушкину ключу, текущему с севера, и по долине р. Тинкан, направляюшейся к югу; но все попытки современных промышленников добывать из этих россыпей золото - терпели неудачу, что и понятно, так как хороших иееликов им древние не оставили〉 (Анерт, 1928. С. 613). Интенсивная эксплуатация россыпных месторождений золота Приморья на протяжении многих лет привела к истощению их геологических запасов, что не могло не отразиться на резком снижении объемов добычи благородных металлов (БМ). Вместе с тем есть веские основания полагать, что минерально-сырьевой потенциал региона далеко не исчерпан. Нужны новые подходы к прогнозу, поискам и освоению источников стратегических минеральных ресурсов. Один из таких альтернативных источников - комплексные проявления экзогенной минерализации, в которых стратегические металлы выступают попутными компо-

(C) Молчанов В. П., Андросов Д. В., 2020 нентами. Издавна к стратегическим металлам относят твердые виды полезных ископаемых, существенные для национальной безопасности. Так, золото обеспечивает финансовую безопасность государства. В последние годы другие металлы приобрели критическую важность для многих промышленных отраслей. Перейдя из категории экзотических металлов в стратегические ресурсы, они оказались крайне востребованными технологиями будущего: редкоземельные элементы - для производства мобильных телефонов, компьютеров, а титан - для применения в медицине и авиастроении и т. д. В конце прошлого века в зарубежной литературе появились понятия «критические металлы» и «критическое минеральное сырье», прочно утвердившиеся в экономике ведущих промышленно развитых стран. Они включают твердые полезные ископаемые, практически незаменимые для развития наукоемких технологий, но крайне рискованные в своем получении потребителем. Многие из этих критических металлов (титан, металлы платиновой группы, редкоземельные элементы, ниобий, тантал, гафний, ванадий, кобальт, сурьма) присутствуют в рудах и россыпях базитов и гипербазитов Приморья, указывая на необходимость проведения геологоразведочных 
работ. Примером тому может послужить Ариадненский массив и сопровождающий его довольно широкий спектр рудо-россыпепроявлений полезных компонентов. Изучение типоморфных свойств основных и попутных россыпеобразующих минералов, в первую очередь ильменита, самородных золота и платины, позволит не только идентифицировать источники питания россыпей и локализовать участки их максимального распространения, но и оценить возможности извлечения этих полезных компонентов.

\section{ОБЪЕКТ ИССЛЕДОВАНИЙ}

Ариадненский массив располагается в центральной части Приморья - среднем течении p. Малиновка (бассейн водосбора р. Большая Уссурка, правого притока р. Уссури, в свою очередь впадающей в р. Амур). Он относится к группе дифференцированных интрузий Кокшаровского комплекса, приуроченных к Самаркинскому террейну юрской аккреционной призмы. В геологическом строении Ариадненского рудно- россыпного узла (рис. 1), совпадающего с контурами одноименного массива, принимают участие позднеюрско-раннемеловые туфо-терригенные образования, позднепермская толща алевролитов и песчаников, а также средне-позднеюрские вулканогенно-кремнисто-терригенные породы с олистостромами. Вулканогенно-осадочные толщи прорваны Ариадненским массивом. Его южная часть сложена перидотитами и оливиновыми пироксенитами, в средней преобладают ильменитовые и роговообманковые габбро, переходящие к северу в диориты, монцодиориты и сиениты. Перечисленные стратифицированные и магматические образования, в свою очередь, прорваны поздними интрузивными телами - гранитоидами, дайками основного и кислого состава позднемелового возраста (Геодинамика..., 2006).

С габброидами связано Ариадненское проявление ильменитовой минерализации (среднее течение р. Падь Тодохова). Рудные тела представляют собой залежи сложной морфологии северо-восточного простирания протяженностью
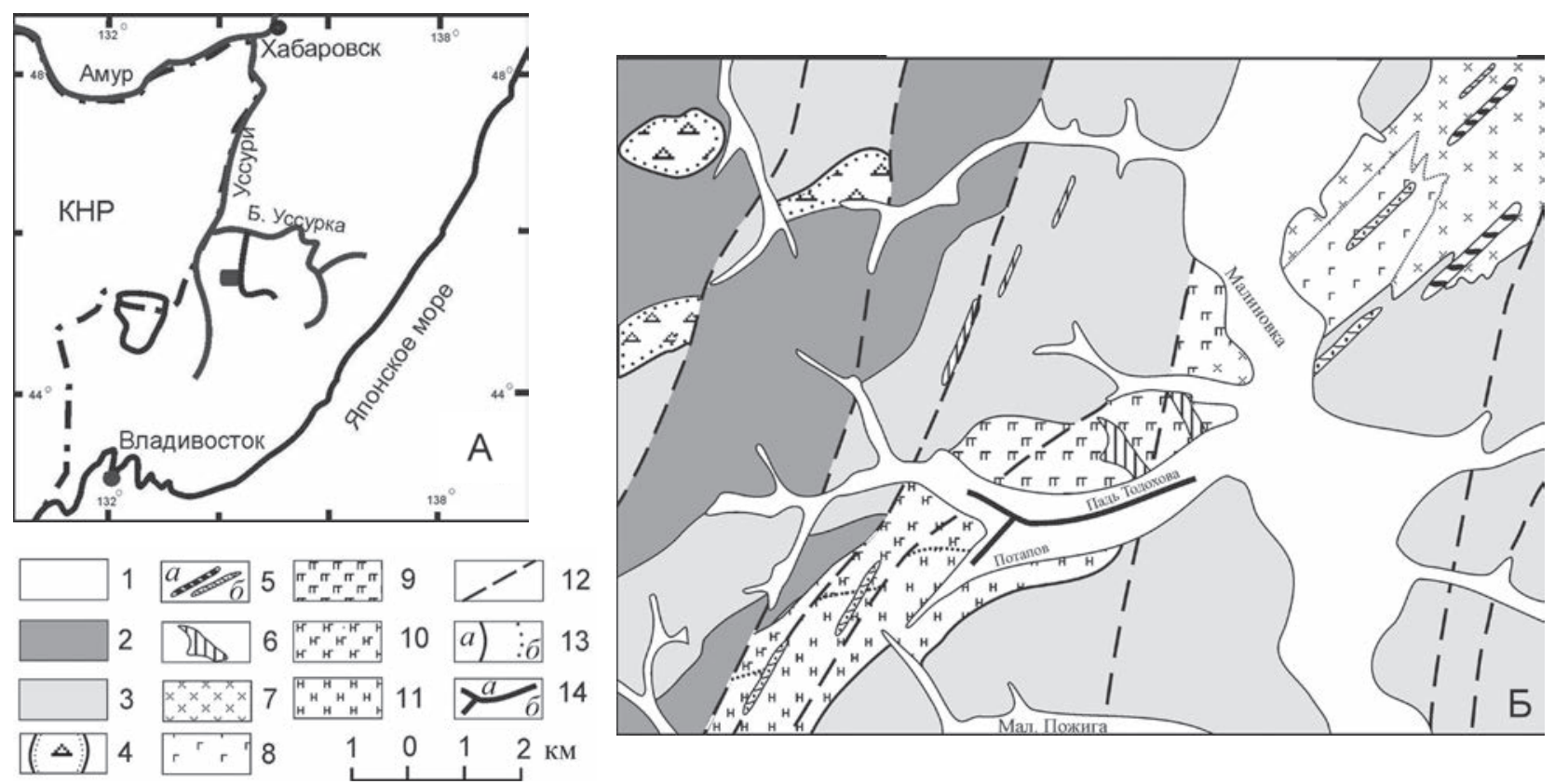

Puc. 1. Схема геологического строения Ариадненского рудно-россыпного узла (составлена авторами с использованием материалов В. М. Лосива, 1990 г.): А - местоположение изученной площади; Б: 1 - четвертичные аллювиальные отложения; 2 - алевролиты, алевролиты с тонкими прослоями песчаников, туффиты (J $\left.-\mathrm{K}_{1}\right)$; 3 переслаивание песчаников и алевролитов $\left(\mathrm{J}_{3}\right) ; 4$ - алевролиты, спилиты, базальты, кремни, кремнистые алевролиты $\left(\mathrm{J}_{2}-\mathrm{J}_{3}\right) ; 5$ - дайки основного $(a)$ и кислого (б) состава $\left(\mathrm{K}_{2}\right) ; 6$ - диориты, кварцевые диориты, гранодиориты $\left(\mathrm{K}_{2}\right) ; 7-11$ - породы Ариадненского массива $\left(\mathrm{J}_{3}-\mathrm{K}_{1}\right): 7$ - диориты, монцодиориты и сиениты; 8 - габбро, ильменитовые габбро; 9 - габбро, пироксениты; 10 - габбро со шлирами перидотитов; 11 - перидотиты; 12 - разрывные нарушения; 13 - границы разновозрастных стратиграфических и интрузивных образований: достоверные $(a)$, фациальные (б); 14 - титаноносные россыпи (a) и точки отбора крупнообъемных проб (б)

Fig. 1. The scheme of the geological structure of the Ariadnensky ore-placer knot (compiled by the authors using the materials by V. M. Losiv, 1990): A - studied area location; Б: 1 - Quaternary alluvial deposits; 2 - siltstones, siltstones with thin sandstone interlayers, tuffites $\left(\mathrm{J}_{3}-\mathrm{K}_{1}\right) ; 3$ - interbedded sandstones and siltstones $\left(\mathrm{J}_{3}\right) ; 4-$ siltstones, spilites, basalts, flintstones, siliceous siltstone, $\left(\mathrm{J}_{2}-\mathrm{J}_{3}\right) ; 5$ - dikes of the basic $(a)$ and acidic ( 6 ) composition $\left(\mathrm{K}_{2}\right) ; 6-$ diorites, quartz diorites, granodiorites $\left(\mathrm{K}_{2}\right) ; 7-11$ - rocks of the Ariadnensky massif $\left(\mathrm{J}_{3}-\mathrm{K}_{1}\right)$ : 7 - diorites, monzodiorites, and syenites; 8 - gabbro, ilmenite gabbro; 9 - gabbro, pyroxenites; 10 - gabbro with peridotite schlieres ; 11 - peridotites; 12 - faults; 13 - boundaries of stratigraphic and intrusive formations of different ages: reliable (a), facial (б); 14 - titaniferous placers ( $a$ ) and bulk sampling points ( $\sigma$ ) 
до 2200 м при ширине до 400 м и прослеженные по падению до 400 м. Среднее содержание $\mathrm{TiO}_{2}$ в них составляет $6.16 \%, \mathrm{~V}_{2} \mathrm{O}_{5}-0.086, \mathrm{Fe}_{2} \mathrm{O}_{3}-13.28$, $\mathrm{Sc}-0.0045$. С глубиной в руде отмечается увеличение концентрации $\mathrm{Cu}$ и $\mathrm{Ni}$, достигающих, coответственно, 0.1 и $0.3 \%$ (по фондовым материалам В. М. Лосива, 1990 г.).

Отличительными чертами мафит-ультрамафитов являются повышенные кларки золота и рутения и пониженные - основной массы элементов платиновой группы. Подтверждением этого может послужить присутствие в базитгипербазитах первичной (магматической) благороднометалльной минерализации. Минералы БМ в протолочках неизмененных ультраосновных пород (Щека, Вржосек, 1985) представлены сперрилитом, золотом высокой и низкой пробности. Высокопробные частицы последнего (Au 93.53 и $\mathrm{Ag}-6.6$ мас.\%) находятся в сростках с ильменитом, клинопироксеном, керсутитом, плагиоклазом. Низкопробное золото ( $\mathrm{Au}-50.59, \mathrm{Ag}-$ 49.7 и $\mathrm{Pd}-0.011$ мас.\%) появляется лишь в тех пробах, где присутствует поздний пирит. В диоритах, как показали наши исследования, распределение золота по пробности также носит бимодальный характер. Высокопробные частицы (Au от 90.17 до 92.43 и $\mathrm{Ag}$ от 7.57 до 9.83 мас.\%) находятся в ассоциации с силикатами (рис. 2,a). простиранию они прослежены до 4000 м, по падению - до 400 м. Главный рудный минерал - антимонит, реже встречаются арсенопирит, пирит, марказит. Содержания основных полезных компонентов варьируют в следующих пределах: $\mathrm{Sb}-$ 0.18-23.4 мас.\% (среднее - 2.2 мас.\%), Ag - 5001820 г/т; $\mathrm{Au}-0.14-0.74$ г/т (среднее - 0.3 г/т) (по фондовым материалам В. М. Лосива, 1990 г.).

Ариадненский массив продуцирует ряд крупных титаноносных россыпей. Авторами (Молчанов, Андросов, 2017) обнаружено самородное золото в шлихах россыпей р. Тодохова и ее правого притока руч. Потапова (см. рис. 1). Протяженность этих аллювиальных россыпей долинного типа составляет соответственно 4.8 и 1.2 км при ширине до 520 и 280 м, при средней мощности продуктивного пласта 7.4 м и содержании ильменита до 375.5 кг/ $\mathrm{M}^{3}$. Балансовые запасы $\mathrm{TiO}_{2}$ категории $\mathrm{C}_{1}+\mathrm{C}_{2}$ по состоянию на 01.01.2019 г. составляют 702 тыс. т, а прогнозные ресурсы достигают 500 тыс. т. В процессе проведения в последние годы геологоразведочных работ по этим объектам получен обширный дополнительный каменный материал, позволяющий значительно расширить представления о природе стратегического минерального сырья ариадненских гипербазитов. Оценка ресурсов попутных компонентов в россыпях при этом не про-
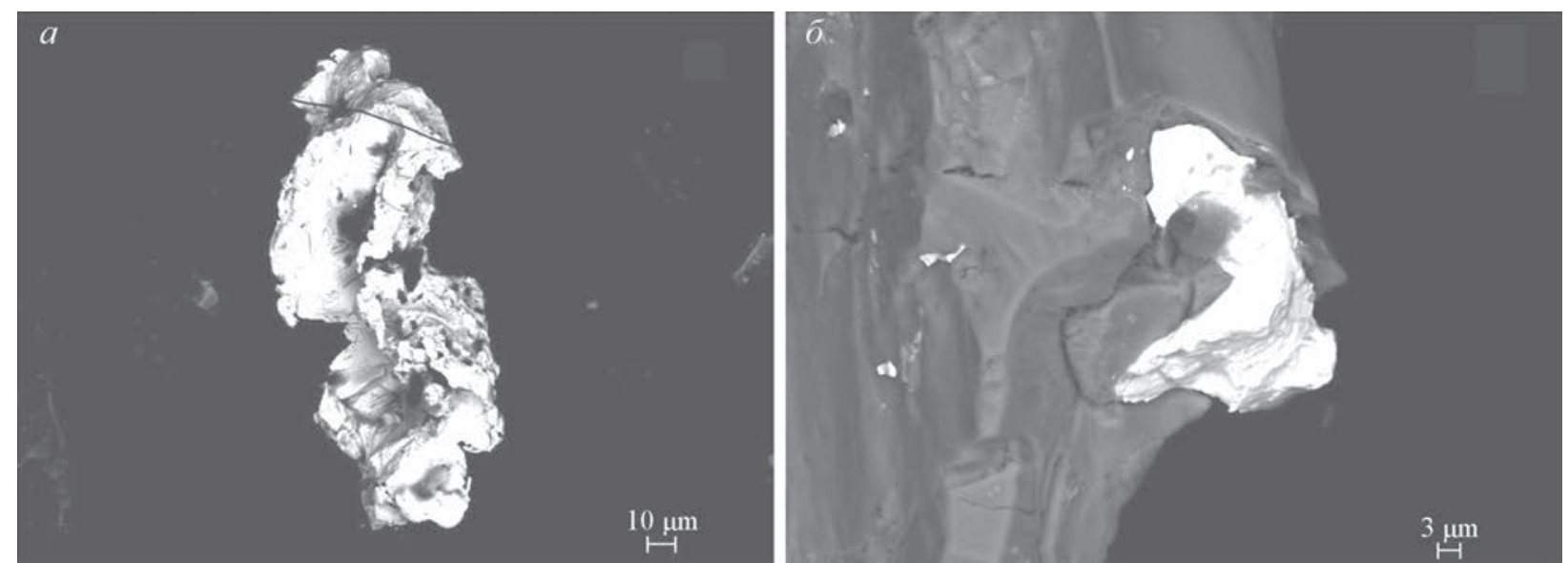

Puc. 2. Морфология самородного золота из диоритов Ариадненского массива: $a$ - высокопробная золотина; б - примазка низкопробного золота на пирите

Fig. 2. Morphology of native gold from the Ariadnensky massif diorites: $a$ - high-grade gold grain; $\sigma$ - low-grade gold adhesion on pyrite

Низкопробное золото (Аu от 76.52 до 80.37 и $\mathrm{Ag}$ от 16.91 до 23.43 мас.\%) фиксируется чаще всего в сростках с пиритом (рис. 2,б).

В верховьях р. Падь Тодохова широко развита сеть северо-восточных разрывных нарушений, контролирующих положение кварцевых жил с золото-сурьмяной минерализацией Тодоховского рудопроявления. Большей частью они приурочены к экзоконтакту базит-ультрабазитов с песчаниками и алевролитами ариадненской свиты. По водилась, что и определило направление наших исследований.

\section{МЕТОДЫ ИССЛЕДОВАНИЙ}

Для решения поставленных задач потребовалось выполнить комплекс минералогических и технологических исследований. В пределах изученных россыпей было отобрано пять крупнообъемных проб (р. Падь Тодохова - 3, кл. Потапова - 2) массой до 500 кг, которые и 
послужили объектами исследований. Анализ микроэлементного состава проб был выполнен на масс-спектрометре с индуктивно связанной плазмой (ИСП-МС) Agilent 7500c (Agilent Technologies, Япония), оборудованном распылителем Бабингтона, охлаждаемой распылительной камерой Скотта и заземленной горелкой Фассела. Использовались никелевые конусы самплера и скиммера. Петрогенные элементы определяли на атомно-эмиссионном с индуктивно связанной плазмой спектрометре iCAP 6500 Duo (ИСПАЭС) (Thermo Scientific, США).

Минералогические исследования осуществляли с применением электронно-зондового микроанализатора Jeol Superprobe JXA 8100 с системой INCA Energy 350 Oxford Instruments и электронного сканирующего микроскопа EVO-500XVP с системой INCA Energy 350 Oxford Instruments.

Технологические исследования были выполнены по традиционной для обогащения ильменитсодержащих песков схеме с предварительным гравитационным обогащением и последующей электромагнитной сепарацией. При этом использовались серийные концентрационные столы и электромагнитные сепараторы мокрого типа.

\section{РЕЗУЛЬТАТЫ ИССЛЕДОВАНИЙ И ИХ ОБСУЖДЕНИЕ}

Предварительные минералогические исследования исходных песков показали, что титан в россыпях представлен исключительно ильменитом, который является главным минералом для промышленного извлечения. Вещественному составу исходных продуктивных песков присуще преобладание $\mathrm{TiO}_{2}$ (19.55 мас.\%), $\mathrm{SiO}_{2}$ (19.72 мас.\%), $\mathrm{Fe}_{2} \mathrm{O}_{3}$ (19.9 мас.\%), $\mathrm{MgO}$ (4.48 мас.\%). Среди постоянных примесей фиксируются редкие, редкоземельные и благородные металлы. Редкоэлементный состав характеризуется присутствием Та (до 100 г/т) и $\mathrm{Nb}$ (до 11 г/т). Концентрации редкоземельных элементов незначительно выше кларкового уровня. Содержание $\mathrm{Au}$ и $\mathrm{Pt}$ редко превышает 0.01 г/т, в то время как Pd присутствует в количествах до 1.1 г/т. Нельзя не обратить внимание на высокий уровень концентрации V (до 730 г/т), Со (340 г/т), $\operatorname{Zn}(230$ г/T).

После этого шлиховые пробы прошли обогащение на гравитационной установке. Полученные концентраты посредством электромагнитной сепарации были разделены на магнитную и немагнитную фракции. Вещественный состав гравитационных концентратов характеризуется высоким выходом магнитной фракции (9395 мас.\%) и низким - немагнитной (5-7 мас.\%). Основу магнитной фракции составляет ильменит (до 95\%). Изредка фиксируются зерна титаномагнетита. Химический состав магнитной фрак- ции характеризуется высокими концентрациями $\mathrm{TiO}_{2}$ (39.79 мас.\%), $\mathrm{Fe}_{2} \mathrm{O}_{3}$ (34.47 мас.\%), $\mathrm{MgO}$ (1.8 мас.\%), $\mathrm{MnO}$ (0.42 мас.\%). Нельзя не отметить повышенные концентрации $\mathrm{SiO}_{2}, \mathrm{Al}_{2} \mathrm{O}_{3}, \mathrm{CaO}$, вероятно, связанных с наличием во фракции сростков ильменита с амфиболами, пироксеном и плагиоклазом. Материал магнитной фракции отличается высоким уровнем присутствия следующих элементов, г/т: $\mathrm{V}-800, \mathrm{Nb}-210, \mathrm{Nd}-100$, $\mathrm{Co}-290, \mathrm{Cu}-490$ и $\mathrm{Zr}-280$.

По данным ситового анализа основная масса ильменита приурочена к классу крупности 1.0 мм, который был принят в качестве продуктивного. При этом в целом по месторождению ильменит представлен следующими фракциями, мас.\%: 0.1 мм - 5.74; 0.1-0.2 мм - 34.74; $0.2-0.5$ мм - 53.24; $0.5-1.0$ мм - 5.70; $1.0-2.0$ мм 0.58 . Данные гранулометрического анализа указывают, что около $80 \%$ основной массы ильменита находится в размерном интервале $0.1-$ 0.5 мм. Какой-либо закономерности распределения ильменита по крупности в вертикальном разрезе россыпей не наблюдается. Отмечен рост доли крупных классов в направлении к верховьм кл. Потапова и р. Падь Тодохова. Средний размер зерен здесь составляет 0.31 и 0.28 мм соответственно.

Согласно требованиям промышленности содержание $\mathrm{TiO}_{2}$ должно быть не менее 45 мас.\%. Для получения магнитных концентратов была применена повторная электромагнитная сепарация с удалением фракции -0.1 мм, где фиксируется основное количество немагнитных составляющих. Это позволило получить ильменитовый концентрат с содержанием $\mathrm{TiO}_{2}$ до 48-50\% и одновременным снижением массовой доли лимитируемых примесей.

Ильменит, в основном свободный, черного цвета, блеск полуметаллический, отмечается в виде кристаллов и их обломков. Кристаллы толстостолбчатые, уплощенные и изометричные, обломки угловатые и угловато-окатанные размером 0.05-2.0 мм. Грани кристаллов и поверхности обломков нередко неровные, грубоямчатые.

Состав ильменитов, по данным микрозондового анализа, характеризуется довольно значительными вариациями содержания основных компонентов (здесь и далее концентрация элементов в мас.\%): $\mathrm{Fe}-31.30-35.15$, Ti - 31.0935.15 , О - 30.02-32.82. Кроме того, в них фиксируется устойчивая примесь Si (до 1.20); Al (до 0.05); $\mathrm{Mg}$ (до 0.49); Сa (до 0.16); V (до 1.10); Mn (до 1,94); Hf (до 1.32). В ямках и на отдельных гранях ильменитов проявляется «лейкоксенизация»: $\mathrm{Ti}-30.29 ; \mathrm{Fe}-6.71 ; \mathrm{Cr}-0.30 ; \mathrm{Ca}-1.07$; $\mathrm{Si}-2.37$; $\mathrm{Al}-0.61 ; \mathrm{Mg}-1.33$; O - 57.32. Исследования естественных поверхностей ильменитов выявили наличие выделений апатита (P - 11.98; $\mathrm{Ca}-0.88 ; \mathrm{O}-45.79 ; \mathrm{Al}-1.21 ; \mathrm{Si}-3.27 ; \mathrm{Fe}-1.85$; $\mathrm{Ni}-0.13$; $\mathrm{La}-8.99$; $\mathrm{Ce}-19.46 ; \mathrm{Nd}-6.42)$, а так- 
же циркона, самородного никеля и интерметаллидов $\mathrm{Pb}-\mathrm{Sn}$.

Немагнитная фракция в сущности представляет собой смесь (мас.\%) анортита (36.9), кварца (24.3), роговой обманки (17.6), сфена (15.4) и циркона (3.8). Кроме того, в незначительных количествах присутствуют монацит, рутил и апатит. Из рудных минералов преобладают сульфиды (единичные зерна пирита, арсенопирита, антимонита и галенита) и самородные металлы (золото, платина, цинк и никель). Немагнитный концентрат характеризуется следующим химическим составом, мас.\%: $\mathrm{SiO}_{2}$ - 49.6; $\mathrm{CaO}$ - 13.2; $\mathrm{Al}_{2} \mathrm{O}_{3}-11.0$; $\mathrm{TiO}_{2}$ - 9.4; $\mathrm{ZrO}_{2}-4.23 ; \mathrm{P}_{2} \mathrm{O}_{5}-4.15 ; \mathrm{Fe}_{2} \mathrm{O}_{3}-3.23$; $\mathrm{MgO}-1.84 ; \mathrm{Na}_{2} \mathrm{O}-1.67 ; \mathrm{K}_{2} \mathrm{O}-1.18 ; \mathrm{V}_{2} \mathrm{O}_{5}-0.096$. Микроэлементы концентрата можно подразделить на две группы. Первая из них включает редкие и редкоземельные элементы (г/т): Нf - 830, $\mathrm{Ce}-320, \mathrm{Y}-220$. Во вторую входят благородные металлы - $\mathrm{Au}, \mathrm{Ag}$ и $\mathrm{Pt}$, концентрации которых меняются в пределах 0.5-3.0 г/т.

Особый интерес вызывают первые находки платиновых минералов в немагнитной фракции рыхлых отложений Ариадненского массива. Для них характерно преобладание твердых растворов $\mathrm{Fe}-\mathrm{Pt}$, которые можно отнести, используя известную номенклатуру (Harris, Cabri, 1991), к изоферроплатине. Железистая платина обычно встречается в виде комковатых зерен неправильной или овальной, уплощенной формы, в поперечнике не превышающих 0.1 мм.

Все золотины, выделенные из немагнитной фракции, по особенностям химизма можно разделить на три группы: серебристую, ртутистую и медистую.

Серебристое золото. В первую, наиболее распространенную группу (до 70\% всех изученных образцов) входят низко- и высокопробные, в понимании Н. В. Петровской (1973), разновидности золото-серебряных соединений. Макроскопически низкопробные фазы - мелкие (менее 0.1 мм) пластинчатые, иногда комковидные частицы желтого цвета. Поверхность золотин мелкоямчатая, окатанность - средняя, иногда хорошая. Они характеризуются сравнительно узким диапазоном колебаний пробности - от 670 до 740\%. На периферии зерен довольно часто наблюдаются гипергенные высокопробные оболочки толщиной 30-50 мкм, где концентрации $\mathrm{Ag}$ (1.6-1.8 мас.\%) значительно понижены по сравнению с центральными частями золотин. Переход от матрицы к кайме резкий и хорошо прослеживается. Появление этих оболочек, по-видимому, связано с выносом примесей из золота в зоне гипергенеза. В отдельных зернах металла наблюдаются мелкие вростки арсенопирита (рис. 3). Химический состав этого минерала ( $\mathrm{Fe}-32.3, \mathrm{As}-42.6, \mathrm{~S}-19.6$ мас.\%) отличается избытком серы и дефицитом мышьяка по отношению к стехиометрии.
Другая разновидность золото-серебряных соединений характеризуется высокими значениями пробности (до 970-999\%о). Спорадически в этих золотинах обнаруживаются дискретные микроскопические обособления самородного серебра. Их появление, скорее всего, связано с гипергенными преобразованиями низкопробного золота. Высвободившееся при этом серебро отлагалось в виде самостоятельных минеральных фаз (см. рис. 3).

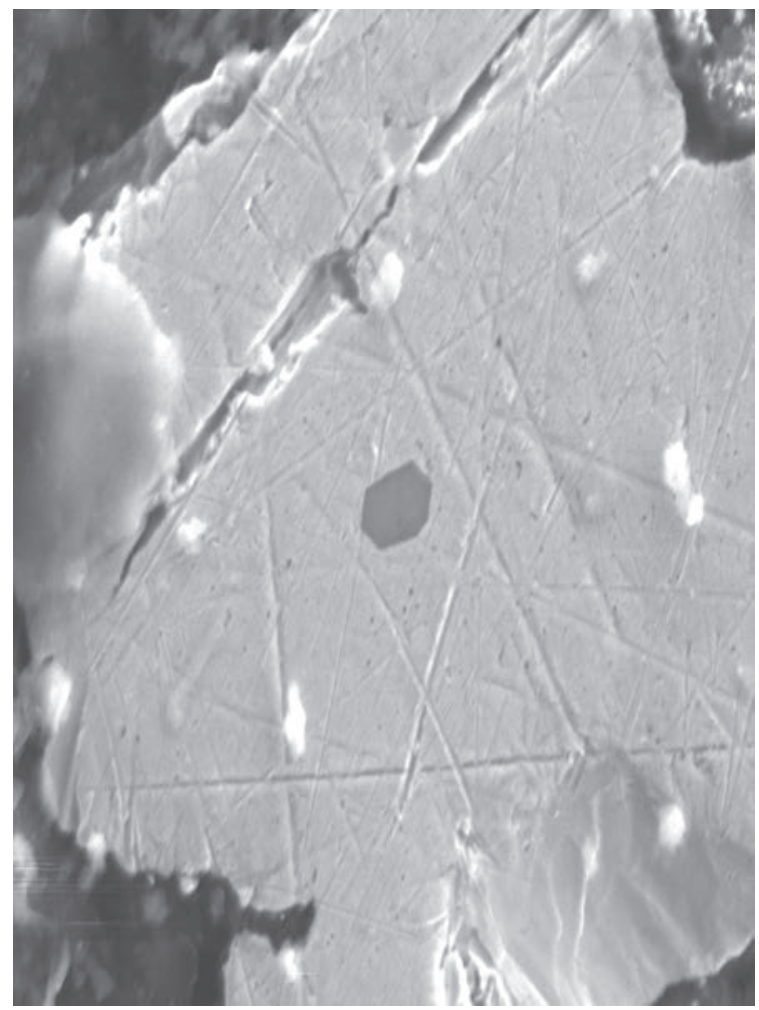

Puc. 3. Включение арсенопирита в центре в самородном золоте, изображение в обратных электронах. Ув. 400

Fig. 3. Inclusion of arsenopyrite in the center in native gold, image in reverse electrons. Mag. 400

Широкое развитие в рыхлых отложениях Ариадненского массива золото-серебряных фаз, возможно, подтверждает участие в россыпеобразовании кварцево-жильных образований Тодоховского проявления золото-сурьмяной минерализации, генетически связанного с поздним гранитоидным магматизмом. Самородное золото подобных образований, по данным Э. М. Спиридонова и П. А. Плетнева (2002), наиболее серебристое в ряду плутоногенных гидротермальных месторождений.

Ртутистое золото. Представлено низкопробными ртутьсодержащими фазами (Au от 53.72 до 55.37 мас.\%, Ag от 39.1 до 41.45 мас.\%, $\mathrm{Hg}$ от 3.47 до 4.31 мас.\%). Они характеризуются невысокой гипергенной устойчивостью (рис. 4,a). Своеобразие вторичных преобразований выразилось в образовании высокопробной пори- 
стой диффузионной зоны шириной до 100 мкм, в которой практически полностью отсутствует $\mathrm{Hg}$ (рис. 4,б). Схожие изменения претерпевало гипогенное ртутистое золото в процессе формирования многих россыпей Урала (Мурзин, Малюгин, 1987). Отличительными чертами такого золота являются пониженные значения пробности, монолитное (плотное) внутреннее строение, прямая корреляция концентраций $\mathrm{Ag}$ и $\mathrm{Hg}$. Подобными характеристиками обладают изученные ртутистые фазы. Это позволяет сделать вывод о синхронной кристаллизации ртути и золота, а
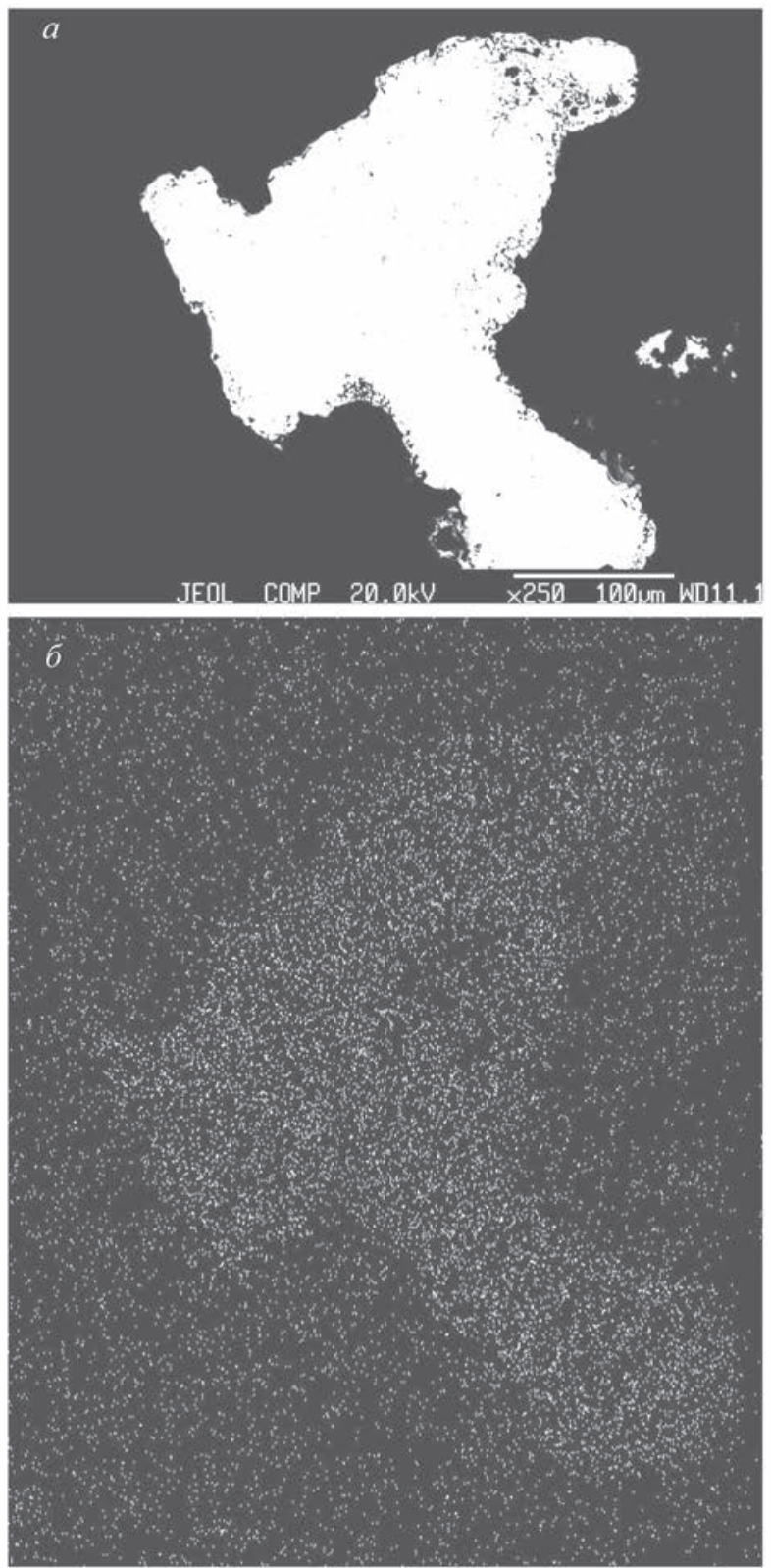

Puc. 4. Гипергенное преобразование Нg-электрума. Белые микрообособления - высокопробное золото. Изображение: $a$ - в обратных электронах; $\sigma$ - в рентгеновских лучах ртути

Fig. 4. Hypergenic conversion of Hg-electrum. White microsegregations are high-grade gold. Image: $a-$ in reverse electrons; $\sigma$ - in mercury X-rays не о техногенном «заражении» шлихового золота в процессе эксплуатации россыпей. Таким образом, изложенные данные позволяют уверенно относить изученное ртутистое золото к природным твердым растворам системы $\mathrm{Au}-\mathrm{Ag}-\mathrm{Hg}$.

Медистое золото. Эта группа состоит из тонких (менее 0.1 мм), относительно изометричных выделений золота ярко-желтого цвета с красноватым оттенком. Типоморфной примесью этих золотин средней пробности (850-900\%) можно считать $\mathrm{Cu}(0.1-3.2$ ат.\%). В процессе микрозондовых исследований установлен неравномерный характер распределений этого элемента. Размер гомогенных участков редко превышает первые десятки микрон.

Ртутистый и медистый состав самородного золота россыпей указывает на «ультрабазитовый» тип коренного источника. Так, находки самородного золота с высокими концентрациями $\mathrm{Cu}$ и $\mathrm{Hg}$ неоднократно отмечались в рудо-россыпепроявлениях, тяготеющих к базит-гипербазитам Урала (Сазонов и др., 2002), Приамурья (Молчанов и др., 2005). В пользу этой точки зрения, в нашем случае, свидетельствует близость макросоставов шлихового золота «ультрамафитового» профиля и его аналогов из ультраосновных пород. Факт сохранения геохимических характеристик россыпных золотин первично-магматического генезиса имеет принципиальное значение, поскольку может использоваться при металлогенических построениях, а также оценке перспектив ресурсного потенциала территорий не только юга Дальнего Востока, но и других регионов.

В то же время нельзя до конца исключать гипотетической возможности обогащения самородного золота за счет мафит-ультрамафитов, послужившими боковыми породами для флюидов, формировавших золото-сурьмяную минерализацию. Это взаимодействие могло сопровождаться выносом $\mathrm{Au}, \mathrm{Cu}, \mathrm{Hg}$ из ультраосновных пород, отличавшихся их повышенной концентрацией по сравнению с эдуктом, и с последующим поступлением этих элементов в гидротермальную систему.

Интерпретация полученных материалов приводит к выводу о том, что процесс формирования коренных источников россыпей Ариадненского узла охватывает длительный период времени. Его можно разделить на два этапа. На первом этапе, предположительно $\left(\mathrm{J}_{2}-\mathrm{K}_{1}\right)$, формировались собственно магматогенные ильменитовая и благороднометалльная минерализации, связанные со становлением дифференцированного массива гипербазитов. Последующая магматическая активизация на втором этапе $\left(\mathrm{K}_{2}\right)$ привела к появлению золото-сурьмяных руд, ассоциирующих с поздними гранитоидными интрузиями. Разрушение упомянутых магматических и рудных образований привело к поступлению в россыпи ильменита и минералов БМ. 


\section{ЗАКЛЮЧЕНИЕ}

Таким образом, всестороннее изучение большеобъемных шлиховых проб из ильменитовых россыпей Ариадненского массива ультраосновных пород позволило установить, что, помимо титана, золота и платины, в них присутствует широкий спектр стратегических металлов, среди которых, прежде всего, необходимо отметить такие промышленно важные, как $\mathrm{V}, \mathrm{Co}, \mathrm{Ta}, \mathrm{Nb}$ и $\mathrm{Pd}$ (см. таблицу). ском плане присутствие разнородных групп золота можно рассматривать как индикатор формирования россыпей с участием нескольких коренных источников. Наиболее активно в этом процессе участвовали базит-гипербазиты Ариадненского массива, поставлявшие стратегически полезные компоненты, в первую очередь ильменит, золото и платину. А находки антимонита и золотин с включениями арсенопирита отражают участие в россыпеобразовании и других коренных источников.

Минералого-геохмические особенности магнитных и немагнитных концентратов титаноносных россыпей Ариадненского массива базит-гипербазитов

Mineralogical and geochemical features of magnetic and non-magnetic concentrates of titanium-bearing placers of the Ariadnensky massif of basite-hyperbasites

\begin{tabular}{|c|c|c|}
\hline \multirow{2}{*}{$\begin{array}{c}\text { Минералого-геохимическая } \\
\text { характеристика }\end{array}$} & \multicolumn{2}{|r|}{ Концентрат } \\
\hline & Магнитный & Немагнитный \\
\hline Химический состав & $\begin{array}{l}\mathrm{TiO}_{2}-39.79 ; \mathrm{Fe}_{2} \mathrm{O}_{3}-34.47 \\
\mathrm{MgO}-1.8 \\
\mathrm{MnO}-0.42\end{array}$ & $\begin{array}{l}\mathrm{SiO}_{2}-49.6 ; \mathrm{CaO}-13.2 ; \mathrm{Al}_{2} \mathrm{O}_{3}-11.0 ; \mathrm{TiO}_{2}-9.4 ; \\
\mathrm{ZrO}_{2}-4.23 ; \mathrm{P}_{2} \mathrm{O}_{5}-4.15 ; \mathrm{Fe}_{2} \mathrm{O}_{3}-3.23 ; \mathrm{MgO}-1.84 \\
\mathrm{Na}_{2} \mathrm{O}-1.67 ; \mathrm{K}_{2} \mathrm{O}-1.18\end{array}$ \\
\hline Стратегические металлы & $\mathrm{V}, \mathrm{Nb}, \mathrm{Nd}, \mathrm{Co}, \mathrm{Cu}$ & $\mathrm{Hf}, \mathrm{Ce}, \mathrm{Y} \mathrm{Au}, \mathrm{Ag}, \mathrm{Pt}$ \\
\hline Рудные минералы & Ильменит, титаномагнетит & $\begin{array}{l}\text { Сульфиды (пирит, арсенопирит, антимонит, гале- } \\
\text { нит) и самородные металлы (золото, платина, } \\
\text { цинк и никель) }\end{array}$ \\
\hline Гранулометрия & $\begin{array}{l}\text { Ильменит }-0.1 \text { мм }-5.74 ; \\
0.1-0.2 \text { мм - 34.74;0.2- } \\
0.5 \text { мм - 53.24;0.5-1.0 мм- } \\
5.70 ; 1.0-2.0 \text { мм - } 0.58\end{array}$ & Благородные металлы - 0.1 мм \\
\hline $\begin{array}{l}\text { Состав основных россыпе- } \\
\text { образующих минералов } \\
\text { (число анализов) }\end{array}$ & $\begin{array}{l}\text { Ильменит (50) } \\
\text { Fе от } 31.30 \text { до } 35.15 \\
\text { Ti от } 31.09 \text { до } 35.15 \\
\text { O от } 30.02 \text { до } 32.82 \\
\mathrm{Si}(\text { до } 1.20) ; \mathrm{Al}(\text { до } 0.05) ; \\
\mathrm{Mg}(\text { до } 0.49) ; \mathrm{Ca}(\text { до } 0.16) ; \mathrm{V} \\
\text { (до 1.10); Mn (до 1.94); } \\
\mathrm{Hf}(\text { до } 1.32)\end{array}$ & $\begin{array}{l}\text { Самородное золото } \\
\text { Серебристое (91): } \\
\text { 1. Аu от } 67.14 \text { до } 74.52 ; \mathrm{Ag} \text { от } 33.61 \text { до } 26.54 ; \\
\text { 2. Аu от } 97.12 \text { до } 100 ; \mathrm{Ag} \text { от } 3.12 \text { до } 0 \\
\text { Ртутистое (22): } \\
\text { Аu от } 53.72 \text { до } 55.37 ; \mathrm{Ag} \text { от } 39.1 \text { до } 41.45 ; \mathrm{Hg} \\
\text { от } 3.47 \text { до } 4.31 \\
\text { Медистое (26): } \\
\text { Аи от } 85.49 \text { до } 90.10 ; \mathrm{Ag} \text { от } 15.61 \text { до } 9.8 ; \mathrm{Cu} \\
\text { от } 0.1 \text { до } 3.2\end{array}$ \\
\hline
\end{tabular}

Примечание. Концентрации компонентов приведены в мас.\%.

Установлено, что основу магнитного концентрата исходного шлихового материала составляет ильменит (до 95-97 мас.\%), который после несложных технологических операций легко доводится до промышленных кондиций. Его отличительной чертой является присутствие повышенных концентраций $\mathrm{V}, \mathrm{Nb}, \mathrm{Nd}, \mathrm{Co}$.

Немагнитный концентрат примечателен присутствием таких дефицитных для промышленности металлов, как Hf, Ce, Y, а применение современных технологий обогащения (Молчанов, 2008) позволит дополнительно извлечь из них благородные металлы $\mathrm{Au}, \mathrm{Ag}, \mathrm{Pt}$ и $\mathrm{Pd}$ с соблюдением ресурсосберегающих принципов и без нанесения существенного урона экологической обстановке.

Минералы благородных металлов в немагнитной фракции представлены серебристой, медистой и ртутистой разновидностями самородного золота, а также железистой платиной. В генетиче-
Извлечение критических металлов из титаноносных песков может повысить рентабельность разрабатываемых объектов. Учет зарубежного опыта технологического передела критического минерального сырья, применительно к условиям нашей страны, позволит более обоснованно наметить пути освоения российских комплексных месторождений.

Работа выполнена при поддержке гранта РФФИ № 20-05-00525.

\section{ЛИТЕРАТУРА}

Анерт Э. Э. Богатство недр Дальнего Востока. Хабаровск : Книжное дело, 1928. 923 с.

Геодинамика, магматизм и металлогения Востока России / под ред. А. И. Ханчука. Владивосток : Дальнаука, 2006. Кн. 1.572 с.

Молчанов В. П. Возможности ресурсосберегающей технологии извлечения полезных компонентов 
из техногенных и прибрежно-морских россыпей юга Дальнего Востока России // Экология и промышленность России. 2008. № 5. С. 41-45.

Молчанов В. П., Андросов Д. В. Минералы благородных металлов Ариадненского массива гипербазитов (Приморье) // Геология и минерально-сырьевые ресурсы Северо-Востока России. Якутск : СВФУ, 2017. C. 142-146.

Молчанов В. П., Зимин С. С., Гвоздев В. И. Роль апогипербазитов в формировании платиноиднозолотых россыпей Гарьского узла (Среднее Приамурье) // Рудные месторождения континентальных окраин. Владивосток : Дальнаука, 2001. Т. 2. Вып. 2. C. 219-232.

Мурзин В. В., Малюгин А. А. Типоморфизм золота зоны гипергенеза (на примере Урала). Свердловск : УНЦ, 1987.96 с.

Поступила в редакиию 06.06.2019 г.

Поступила после доработки 18.07.2019 2.
Петровская Н. В. Самородное золото. Москва : Наука, 1973. 345 с.

Сазонов В. Н., Мурзин В. В., Огородников В. Н. Золотое оруденение, сопряженное с альпинотипными ультрабазитами (на примере Урала) // Литосфера. 2002. № 4. С. 63-77.

Спиридонов Э. М., Плетнев П. А. Месторождение медистого золота Золотая гора (о «золото-родингитовой» формации). Москва : Науч. мир, 2002. 220 с.

Щека С. А., Вржосек А. А. Редкий тип магматической платино-золотой минерализации в базит-гипербазитовых интрузиях // Типоморфные ассоциации акцессорных минералов и микроэлементов. Владивосток : ДВНЦ АН СССР, 1985. С. 82-85.

Harris D. C., Cabri L. J. Nomenclature of platinumgroup-elements alloys. Review and revision // The Canadian Mineralogist. 1991. Vol. 29. P. 231-237.

\title{
STRATEGIC METALS OF TITANIFEROUS PLACERS ASSOCIATED WITHIN THE ARIADNENSKY MASSIF OF HYPERBASITES (Primorye)
}

\author{
V. P. Molchanov ${ }^{1}$, D. V. Androsov ${ }^{2}$ \\ ${ }^{1}$ Far East Geological Institute, FEB RAS, Vladivostok \\ ${ }^{2}$ ITERA Ltd., Dalnerechensk
}

\begin{abstract}
Long-term intensive mining of precious metals from placers in Primorsky Krai has resulted in the depletion of their geological reserves. Strengthening the material base of the area is associated with complex exogenous deposits in which strategic metals are associated components. The composition of ilmenite, native gold, and platinum from titanium-bearing placers, spatially and genetically related to the Ariadnensky massif of basite-hyperbasites (left bank of the Ussurka River), was studied. The data obtained permitted to make a conclusion on the participation of polygenic and polychronous indigenous sources in placer formation. Mafic ultramafites acted as a supplier of ilmenite, platinum, copper, and mercury gold. Another source for feeding placers apparently was quartz-lode formations with gold-antimony mineralization. The experience of extracting strategic minerals from a variety of minerals requires careful study in relation to the conditions of the Far East.
\end{abstract}

Keywords: gravity, electromagnetic separation, ilmenite, platinum, argentiferous gold, copper gold, mercury gold, titanium-bearing placer, mafite-ultramafite, Ariadnensky massif, Primorsky Krai.

\section{REFERENCES}

Anert, E. E., 1928. The Wealth of Mineral Resources of the Far East. Khabarovsk, Knizhnoye Delo [In Russian].

Geodynamics, Magmatism, and Metallogeny of the East of Russia, 2006, Ed. A. I. Khanchuk. Vladivostok, Dal'nauka, 1 [In Russian].

Harris, D. C., Cabri, L. J., 1991. Nomenclature of Platinum-Group-Elements Alloys, Review and Revision, The Canadian Mineralogist. 29, 231-237.

Molchanov, V. P., 2008, Potentials of Resource-Saving Technologies of Useful Components Extraction from Technogenic and Coastal-Sea Placers of the Southern Region of Russia's Far East, Ecology and Industry of Russia. 5, 41-45 [In Russian].

Molchanov, V. P., Androsov, D. V., 2017. Minerals of Precious Metals of the Ariadnensky Massif of Hyperbasites (Primorye), Geology and Mineral Resources of the North-East of Russia. Yakutsk, 142-146 [In Russian].

Molchanov, V. P., Zimin, S. S., Gvozdev, V. I., 2001. The Role of Apohyperbasites in the Formation of Pla-
tinoid-Gold Placers of the Garsky Knot (Central Priamurye), Ore Deposits of Continental Margins. Vladivostok, Dal'nauka, 2, 219-232 [In Russian].

Murzin, V. V., Malyugin, A. A., 1987. Gold Typomorphism of the Hypergenesis Zone (Exemplified by the Urals). Sverdlovsk [In Russian].

Petrovskaya, V. N., 1973. Native Gold. Moscow, Nauka [In Russian].

Sazonov, V. N., Murzin, V. V., Ogorodnikov, V. N., 2002. Gold Mineralization Associated with Alpine-Type Ultrabasites (Exemplified by the Urals), Lithosphere. 4, 63-77 [In Russian].

Scheka, S. A., Vrhosek, A. A., 1985. A Rare Type of Magmatic Platinum-Gold Mineralization in Basite-Hyperbasic Intrusions, Typeomorphic Associations of Accessory Minerals and Microelements. Vladivostok, 82-85 [In Russian].

Spiridonov, E. M., Pletnev, P. A., 2002. Gold Mountain Copper Gold Deposit (on the "Gold-Rodingite" Formation). Moscow, Scientific World [In Russian]. 